\title{
Now Dew Disease Reports \\ Molecular characterisation and first complete genome sequence of Tomato yellow leaf curl virus (TYLCV) infecting tomato in Iraq
}

N. Al-Kuwaiti ${ }^{1,2 *}$, B. Otto ${ }^{1,3}$, C. Collins ${ }^{1,4}$, S. Seal ${ }^{1}$ and M. Maruthi ${ }^{1}$

${ }^{1}$ Natural Resources Institute, University of Greenwich at Medway, Chatham Maritime, Kent ME4 4TB, UK; ${ }^{2}$ Plant Protection Department, College of Agriculture, University of Baghdad, Abu Ghraib, Baghdad, Iraq; ${ }^{3}$ Department of Forest Botany and Tree Physiology, Büsgen-Institut, Georg-August Universität Göttingen, Büsgenweg 2, D-37077 Göttingen, Germany; ${ }^{4}$ Department of Bioagricultural Sciences and Pest Management, Colorado State University, Fort Collins, CO 80523-1177, USA

*E-mail: sn47@gre.ac.uk

Received: 25 Mar 2013. Published: 18 May 2013. Keywords: RCA, phylogeny, restriction digestion, protected fields, primers

Tomato yellow leaf curl disease (TYLCD, genus Begomovirus, family Geminiviridae) is one of the factors that severely limits tomato production in Iraq, as it attacks tomato cultivated in both protected and open fields (Al-Fadhal, 2012). In Iraq, TYLCD incidence may reach up to $100 \%$ and can cause economic losses between 50-90\%, especially when the virus infects tomato plants in the early growing stages (Al-Ani et al., 2011). In April 2010 leaf curling, yellowing and a reduction in leaf size symptoms were observed on tomato in fields in Baghdad, Iraq. A total of 49 tomato samples were collected and total nucleic acids were extracted from samples using the CTAB protocol described by Abarshi et al. (2010). PCR amplifications of extracted nucleic acids were performed using Red Hot DNA polymerase (Thermo Scientific Inc., USA) and begomovirus specific primers (Deng et al., 1994). Rolling circle amplification (RCA) was performed using an Illustra Templiphi 100 Amplification Kit (GE Healthcare Limited, UK) according to the manufacturer's protocol. Restriction digestion of RCA products with $\mathrm{NcoI}$ was performed to release the full-length fragment of the amplified viral DNAs, which were gel purified, cloned and sequenced (Bioscience Gene Service, UK). Based on PCR and sequence analyses using MEGA 5 software (Tamura et al., 2011), six out of 49 tomato samples (12\%) were found to be infected by TYLCV. MEGA BLAST search of sequences amplified by Deng primers revealed that sequences isolated showed $98 \%$ maximum identity with Tomato yellow leaf curl virus GenBank sequences.

The full length sequence referred to as TYLCV IRQ is $2780 \mathrm{bp}$ in length (GenBank Accession No. JQ354991). Sequence comparison of full length TYLCV-Iraq1 using MEGA BLAST search was performed against available GenBank sequences. TYLCV IRQ shared $99 \%$ identity with TYLCV isolates Mauritius (HM448447) from Mauritius, RE4 (AM409201) from Reunion Island and Almeria (AJ489258) from Spain. The primer pair 'TYLCV-F/TYLCV-R' (TYLCV-F, 5'-GGATAAGCACATGGAGATGTG-3' and TYLCV-R, 5'-CAAGATAACAGAACAC AGCCA-3') was designed from the TYLCV IRQ isolate to amplify a $1.7 \mathrm{~kb}$ fragment from the TYLCV genome regions between 1394-2463 nucleotide positions. This primer could detect TYLCV in all six tomato samples previously tested using the Deng primer set (Fig. 1). Phylogenetic (neighbour-joining) analysis of full sequence of TYLCV IRQ and those sequences from GenBank grouped

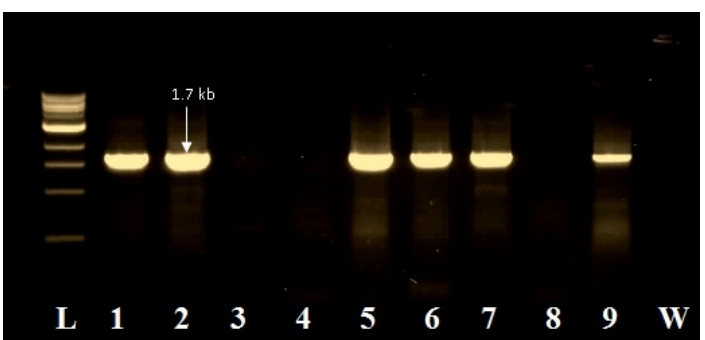

Figure 1
TYLCV IRQ within the TYLCV cluster but diverged this sequence into a separate clade from the TYLCV isolates from Spain, Reunion Island, Morocco, New Caledonia, and The Netherlands (Fig. 2). This separate grouping of TYLCV- Iraq1 from other GenBank TYLCV sequences is supported by a bootstrap value of $89 \%$, which may indicate a distinct origin for TYLCV IRQ. This study provides the first molecular evidence of TYLCD in Iraq.

\section{Acknowledgements}

The authors would like to Dr. A. Al-Kuwaiti, and Mr. M. A. Adhab for their excellent technical assistance.

\section{References}

Abarshi MM, Mohammed IU, Wasswa P, Hillocks RJ, Holt J, Legg JP, Seal SE, Maruthi MN, 2010. Optimization of diagnostic RT-PCR protocols and sampling procedures for the reliable and cost-effective detection of Cassava brown streak virus. Journal of Virological Methods 163, 353-359. [http://dx.doi.org/10.1016/j.jviromet.2009.10.023]

Al-Ani RA, Adhab MA, Hamad SA, 2011. Evaluation of the efficiency of different techniques for extraction and purification of Tomato yellow leaf curl virus (TYLCV). Journal of Baghdad for Science 8, 447-452 [In Arabic, English abstract].

Al-Fadhal FA, 2012. Biological and serological properties of Tomato yellow leaf curl virus (TYLCV). Biology Journal of Al-Kufa University 4 , 139-145 [In Arabic, English abstract]. [http://dx.doi.org/10.1111/j.1744-7348.1994.tb04973.x]

Deng D, McGrath PF, Robinson DJ, Harrison BD, 1994. Detection and differentiation of whitefly-transmitted geminivirus in plants and vector insects by the polymerase chain reaction with degenerate primers. Annals of Applied Biology 125, 327-336, 1994.

Tamura K, Peterson D, Peterson N, Stecher G, Nei M, Kumar S, 2011. MEGA5: Molecular evolutionary genetics analysis using maximum likelihood, evolutionary distance, and maximum parsimony methods. Molecular Biology and Evolution 28, 2731-2739.

[http://dx.doi.org/10.1093/molbev/msr121]

To cite this report: Al-Kuwaiti N, Otto B, Collins C, Seal S, Maruthi M, 2013. Molecular characterisation and first complete genome sequence of Tomato yellow leaf curl virus (TYLCV) infecting tomato in Iraq. New Disease Reports $27,17$. [http://dx.doi.org/10.5197/j.2044-0588.2013.027.017] 